\title{
Labor Supply Effects of Federal Rental Subsidies ${ }^{1}$
}

\author{
Will Fischer \\ Berkeley Policy Associates, 440 Grand Avenue, Suite 500, Oakland, California 94610-5085 \\ E-mail:will@bpacal.com \\ Received February 4, 2000

\begin{abstract}
Federal rental subsidies appear to create disincentives for work through marginal taxes on earnings, income effects, and requirements that nonrecipients on waiting lists maintain low incomes in order to remain eligible. This paper takes advantage of the rationing of housing subsidies by identifying labor supply effects using analytic methods that could not be validly applied to unrationed programs. It finds that subsidies substantially reduce hours worked and labor force participation among recipients. (C) 2000 Academic Press

Key Words: housing; labor supply.
\end{abstract}

Federal rental subsidies delivered through the public housing and Section 8 voucher and certificate programs impose effective marginal tax rates as high as $30 \%$ on households as their earnings rise. In addition, the subsidy programs provide a substantial source of unearned income to recipients and require nonrecipients on waiting lists to maintain low incomes in order to remain eligible. These characteristics would be expected to reduce labor supply among those households that are potentially eligible for housing assistance.

This paper attempts to determine whether these apparent work incentives actually affect labor supply decisions. In order to avoid the difficulties associated with using variation in subsidy characteristics to estimate the entire effect of rental subsidies on the labor market, it attempts instead to identify specific parts of that effect. It employs two methods to do so.

First, it compares the labor supply, represented by annual hours worked and labor force participation, of Aid to Families with Dependent Children (AFDC) recipients who received housing assistance with the labor supply of those who do not. Because nearly all AFDC recipients were income eligible for housing assistance, this approach avoids much of the endogeneity problem that requires the use of more complex methods to identify labor supply effects. To test the impact of the size of maximum housing subsidies, it conducts a difference-indifference analysis comparing the labor supply of AFDC recipients on and off

\footnotetext{
${ }^{1}$ An earlier draft was released as publication P99-001 of the Program on Housing and Urban Policy at the University of California, Berkeley. I am grateful to John Quigley and Hilary Hoynes for comments and suggestions.
} 
housing assistance as subsidy size varies. To avoid the complications involved with using variation in FMRs as a source of variation in subsidy size, this analysis uses the effect of changes in AFDC benefits on the calculation of housing subsidies to explain this variation. It finds large and significant effects, indicating that, at least among AFDC recipients, subsidies had a substantial income effect on labor supply.

The second analysis compares labor supply levels among households before and after they begin receiving subsidies. Since households must establish eligibility beforehand in order to be placed on a waiting list, this approach isolates the income and marginal tax effects of actually receiving subsidies both from exogenous labor supply change that makes households eligible and from labor supply changes made deliberately in response to the waiting list requirements. Overall, the analysis found that subsidies had a statistically significant negative effect on labor force participation and a substantial, but statistically insignificant, negative effect on hours. Parameterizing these effects to reflect labor supply trends in a larger population of public assistance recipients eliminated their remaining statistical significance but did not reduce their magnitude.

These findings take on a somewhat different policy implication than they would in the context of an unrationed housing assistance program. A smaller, more broadly distributed subsidy would reduce the number of families exposed to the most extreme distortions of work incentives, and it could also reduce the overall effect of subsidies on labor supply.

\section{OVERVIEW OF FEDERAL RENTAL SUBSIDY PROGRAMS}

This paper discusses three federal rental subsidy programs: public housing, Section 8 certificates, and Section 8 vouchers. Public housing provides recipients with use of a publicly owned unit, with the size determined by the household's size and composition. Households are required to pay $30 \%$ of their adjusted income as rent. This adjustment counts benefits from Temporary Assistance to Needy Families (TANF, formerly AFDC) as income, but not the Earned Income Tax Credit (EITC), Food Stamps, or most other forms of public assistance.

Section 8 certificates allow recipients to live in private housing units with monthly rents at or below the local FMR. The FMR is defined as the rent of a safe and sanitary unit in the $40^{\text {th }}$ percentile of rents for units with the same number of bedrooms in a particular county or Metropolitan Statistical Area (MSA). The tenant contribution to the rent is calculated according to the same formula used for public housing. The government pays the remaining portion to the landlord. Section 8 vouchers function similarly but allow tenants to choose to live in units with rents above the FMR. The voucher pays a share of the rent equal to the FMR minus $30 \%$ of the household's adjusted income.

In order to be eligible for any of the three programs, most households must 
have "very low incomes," defined as below 50\% of the median income for households of the same size in the same county or MSA. Local housing authorities can also provide small quotas of subsidies to households with incomes between the very low-income threshold and a "low-income" threshold at $80 \%$ of the local median. However, most authorities choose to limit assistance to very low-income households (Painter, 1997; Nelson and Khadduri, 1992).

Once a household is receiving assistance, its income can rise above the very low-income threshold without causing the household's aid to be cut off. Households receiving Section 8 certificates and vouchers can earn up to the 50\% lowincome threshold without losing assistance. However, in many cases the subsidy formula would already have reduced benefits to zero by this point. Public housing households are allowed to remain in their units and pay $30 \%$ of their incomes in rent no matter how much they earn.

Federal rental subsidies are not provided to all eligible households. Instead, assistance is rationed and most households must go on a waiting list for a period before they actually begin receiving benefits. Waiting lists vary in length from one housing authority to another. In 1998, the average subsidy recipient had waited 21 months before receiving aid (U.S. Department of Housing and Urban Development, 1998). Federal program staff report that housing authorities usually provide households on waiting lists with estimates of how much longer they will have to wait and require them to show their eligibility regularly. "Federal preferences" allow households who live in substandard housing, who have been involuntarily displaced from their previous homes, or who pay more than $50 \%$ of their income in rent to move to the head of waiting lists. In addition, housing authorities are permitted to set "local preferences" to give priority to particular types of households.

\section{LABOR SUPPLY DISINCENTIVES UNDER FEDERAL RENTAL SUBSIDIES}

Federal rental subsidy programs would be expected to discourage work through three mechanisms: the effective marginal tax that declining benefits place on rising earnings, the income effect of the subsidy, and the eligibility requirements to which households are required to adhere while they are on waiting lists.

\section{Marginal Tax Effects}

Under all three programs, benefits are reduced by $\$ 0.30$ for every dollar increase in countable income. Households who receive housing assistance therefore face higher marginal tax rates on their earnings than do nonrecipients.

Since Temporary Assistance to Needy Families (TANF) benefits are counted as income under the housing subsidy formula and are phased out as earnings 
rise, housing assistance imposes smaller marginal taxes on TANF participants than on other subsidy recipients. For example, a household in a state where TANF benefits are reduced by $\$ 0.67$ per dollar earned would only gain $\$ 0.33$ in countable income for every additional dollar earned. As a result, the size of the housing subsidy would fall by only $\$ 0.10$ (30\% of $\$ 0.33$ ) when earnings rose by a dollar.

Food Stamp benefits do not affect the calculation of housing subsidies, but for some households receipt of housing subsidies reduces Food Stamp benefits. The Food Stamp benefit formula allows families to deduct up to $\$ 250$ in "excess shelter costs" from their countable income, and receipt of a housing subsidy reduces the costs that can be counted toward this deduction. The Food Stamp formula lowers Food Stamp benefits for households using the excess shelter cost deduction by $\$ 0.30$ for every dollar increase in the housing subsidy, in effect reducing the marginal tax added by housing programs to $\$ 0.21$ for every dollar in earnings. As a result of these interactions, the effect of housing assistance on marginal tax rates depends on where a household lives and what types of assistance it receives. Subsidies add 30\% to the marginal taxes of households receiving only housing benefits, and they add smaller increments to the marginal taxes of households participating in TANF or Food Stamps.

Appendix A shows incomes and marginal taxes for a range of earnings levels with and without housing assistance in four cities for a single parent with two children receiving TANF, Food Stamps, and the EITC during 1998. The household experiences a tax increment of $30 \%$ from housing subsidies in many income brackets, but the increment varies greatly and actually becomes negative in one bracket where the family experiences a sharp decline in Food Stamp benefits.

For households who participate in multiple income-support programs, the housing assistance marginal tax rate is often added onto total marginal tax rates that are already quite high. This is particularly true for the case of monthly earnings, between $\$ 800$ and $\$ 1,600$ for a single parent with two children, for which a household experiences decreases in the EITC, Food Stamps, and, in some states, TANF along with housing subsidies. As Table I shows, marginal tax rates in this earnings bracket for households not receiving subsidies range from $64 \%$ to $87 \%$. With housing subsidies included, tax rates rise by between $10 \%$ and $22 \%$ and reach as high as $97 \%$ in Los Angeles. As shown in Appendix A, total marginal tax rates within shorter earnings intervals sometimes exceed $100 \%$.

These calculations omit a number of means tested programs, the most important of which are Medicaid and childcare subsidies. Medicaid is not included because its value is difficult to measure, and because the provision of transitional benefits to households leaving AFDC complicates the relationship between income and eligibility. Childcare subsidies are left out because they are rationed to a fraction of the eligible population in many states. For many households, however, loss of these types of benefits would substantially raise overall marginal taxes.

It should also be noted that some recipients would experience a sharp reduction 
TABLE I

Incomes and Marginal Tax Rates of Federal Housing Assistance (FHA) Recipients and Nonrecipients in Four Cities

(Family of Three Participating in TANF, Food Stamps, and the EITC)

\begin{tabular}{lrrrrr}
\hline City & $\begin{array}{c}\text { Total } \\
\text { income } \\
\text { at } \$ 0 \\
\text { earnings }\end{array}$ & $\begin{array}{c}\text { Marginal } \\
\text { tax } \$ 0 \\
\text { to } \$ 800 \\
\text { earnings }\end{array}$ & $\begin{array}{c}\text { Total } \\
\text { income } \\
\text { at } \$ 800 \\
\text { earnings }\end{array}$ & $\begin{array}{c}\text { Marginal } \\
\text { tax } \$ 800 \\
\text { to } \$ 1,600 \\
\text { earnings }\end{array}$ & $\begin{array}{r}\text { Total } \\
\text { income } \\
\text { at } \$ 1,600 \\
\text { earnings }\end{array}$ \\
\hline Dallas, TX, with FHA & $\$ 1,147$ & $22.4 \%$ & $\$ 1,768$ & $84.5 \%$ & $\$ 1,892$ \\
Without FHA & $\$ 517$ & $-4.4 \%$ & $\$ 1,352$ & $62.3 \%$ & $\$ 1,654$ \\
FHA increment & $\$ 630$ & $26.8 \%$ & $\$ 416$ & $22.3 \%$ & $\$ 238$ \\
Los Angeles, CA, with FHA & $\$ 1,332$ & $27.9 \%$ & $\$ 1,909$ & $96.8 \%$ & $\$ 1,935$ \\
Without FHA & $\$ 840$ & $11.8 \%$ & $\$ 1,546$ & $86.5 \%$ & $\$ 1,654$ \\
FHA increment & $\$ 492$ & $16.1 \%$ & $\$ 363$ & $10.3 \%$ & $\$ 281$ \\
Philadelphia, PA, with FHA & $\$ 1,242$ & $32.1 \%$ & $\$ 1,785$ & $85.4 \%$ & $\$ 1,902$ \\
Without FHA & $\$ 739$ & $21.5 \%$ & $\$ 1,367$ & $64.1 \%$ & $\$ 1,654$ \\
FHA increment & $\$ 503$ & $10.6 \%$ & $\$ 418$ & $21.3 \%$ & $\$ 248$ \\
Scranton, PA, with FHA & $\$ 1,010$ & $32.1 \%$ & $\$ 1,553$ & $85.4 \%$ & $\$ 1,670$ \\
Without FHA & $\$ 739$ & $21.5 \%$ & $\$ 1,367$ & $64.1 \%$ & $\$ 1,654$ \\
FHA increment & $\$ 271$ & $10.6 \%$ & $\$ 186$ & $21.3 \%$ & $\$ 16$ \\
\hline
\end{tabular}

in benefits (a "notch") at the point where their earnings cross the low-income threshold and they lose eligibility for benefits. Public housing households, however, would not face a notch. Section 8 households would only experience a sharp drop-off in benefits if the low-income threshold in their area were low enough or the FMR high enough that the subsidy would not already have fallen to zero before the household reached the threshold. The subsidized family with two children examined in the calculations discussed above would not experience a notch in any of the selected locations.

\section{Income Effects}

Independent of any changes in benefits as earnings rise, federal rental subsidies could reduce labor supply through an income effect. Households who report very low earnings survive on a combination of public assistance and unreported income from friends, family, private charities, or informal jobs (Edin and Lein, 1997). Those who lack these additional resources would be expected to supply more labor.

Housing assistance provides a substantial portion of the incomes of subsidized households with very low earnings. For the family of three in the calculations discussed above, the share of income provided by housing assistance at zero earnings ranges from $34 \%$ in Scranton, Pennsylvania, to $56 \%$ in Dallas, Texas. Households that receive housing benefits are more likely to be able to collect sufficient resources to survive without reporting additional work hours than those 
who do not. As a result, even if there were no marginal tax rate, it would be expected that households receiving subsidies would have lower labor supply than other households.

\section{Waiting List Effects}

The combination of rationing and eligibility requirements creates work disincentives for households who are not yet receiving benefits but expect to in the near future. A household that is seeking benefits but is not yet receiving them has to maintain an income below the very low-income threshold to enter and stay on a waiting list. In addition, households face incentives to qualify for federal preferences toward families who spend more than half of their incomes on shelter.

\section{OBSTACLES TO USING VARIATION IN RENTAL SUBSIDY CHARACTERISTICS TO IDENTIFY LABOR SUPPLY EFFECTS}

Several existing papers attempt to determine whether and to what extent hypothesized work disincentives of means-tested public assistance programs actually affect labor supply. In order to avoid difficulties related to endogeneity between program participation and labor supply, many of these efforts have measured the relationship between labor supply and exogenously determined program characteristics, such as maximum benefit size (see, for example, Blank, 1985). Painter (1997) and Currie and Yelowitz (1998) attempt to measure the labor supply effects of federal rental subsidies using variation in subsidy characteristics, including FMRs, the very low-income limit used to determine subsidy eligibility, and waiting time length. Both studies conclude that subsidies have substantial negative effects on labor supply. ${ }^{2}$

There are, however, difficulties involved with identifying and representing exogenous variation in these subsidy characteristics. The fact that FMRs are derived directly from a U.S. Department of Housing and Urban Development (HUD) estimate of the housing costs faced by low-income renters in a particular area and year creates two problems for their use in measuring labor supply effects. First, since housing costs are a major component of local economies, a correlation between labor supply and FMR could occur through some mechanism related to housing costs but unrelated to housing subsidies. Second, variation in FMRs does not necessarily represent actual variation in subsidy value, since a substantial

${ }^{2}$ A third paper, Keene and Moffitt (1998), uses a simulation estimator to estimate a structural model of labor supply and participation in several income support programs for female heads of households. It uses fair market rents to represent the size of the maximum housing subsidy. Keene and Moffitt find significant effects on labor supply and program participation for AFDC, Medicaid, and Food Stamps, but not for housing subsidies. They suggest that they did not detect a significant effect for housing benefits because their model was not able to account for the effects of rationing. 
portion of the variation in FMRs will simply reflect higher local costs for housing of a constant quality.

The relationship between FMRs and local housing costs could be controlled for through inclusion of fixed-effect variables for years and localities. However, trends in housing costs and value affect different localities at different times, and any difference between the FMRs estimated by HUD and actual housing costs would seem as likely to be random as to be a constant effect of a year or a locality. Another approach would be to adjust FMRs using an index of housing costs. However, FMRs, which are based on an annual MSA-level HUD estimate of $40^{\text {th }}$ percentile rents that uses information from the Census, the between-census American Housing Survey, Consumer Price Index data, and random digit dialing surveys, are probably nearly as good an indicator of housing costs faced by lowincome households as other cost indices would be. ${ }^{3}$

An additional, though probably less serious, problem with using variation in FMRs to measure labor supply effects is that even if they did not vary in tandem with costs, FMRs would only be an approximation of the value of the maximum subsidy. The maximum subsidy received by a public housing household is really the free use of a unit whose value may or may not be close to the FMR. For Section 8 households, whose subsidies consist of a quantity of private housing whose market value is directly tied to the FMR, the FMR is the value of the maximum subsidy only if it is less than or equal to the amount that the household would have spent on housing if it received a cash grant of the same amount. Moffitt (1989) showed that Food Stamps are essentially equivalent to cash, but it is not certain that a housing subsidy, often several hundred dollars larger than the Food Stamp grant, would be equally fungible.

The use of other characteristics of housing subsidies as instrumental variables in measuring labor supply encounters difficulties as well. The very low-income limit is linked quite directly to the earnings of people toward the lower end of the income distribution, and it would therefore be very likely to interact with labor supply through mechanisms other than housing subsidies. The relationship between the length of waiting periods and labor supply effects is probably too complex to allow its use as an instrumental variable. On the one hand, waiting list length could be interpreted as a factor that reduces the net benefits of housing subsidies through delay, therefore weakening their effect and correlating positively with labor supply. On the other hand, waiting list length would likely be closely associated with the number of people on waiting lists and subject to the waiting list labor supply effects described earlier, a relationship which would create a

${ }^{3}$ In addition, a cost index controls not only for geographic variation in costs for units of similar quality but also for variation in average housing quality, amenities, and economic opportunities that are capitalized into housing costs. Since the first type of variation would not affect real subsidy value but the second type would, adjusting by cost might underestimate the value of subsidies in areas where housing is actually more valuable (see Painter, 1997). 
negative correlation with labor supply. In an empirical analysis, it would be difficult to determine what type of correlation should be taken as confirmation of a labor supply effect.

\section{EMPIRICAL ANALYSES}

While the characteristics of federal rental subsidy programs make it very difficult to use variation in subsidy characteristics to estimate the entire effect of subsidies on labor supply, they also create opportunities for other approaches that could not be applied to unrationed income support programs. This paper employs two such methods. First, it compares the labor supply of AFDC participants who receive housing subsidies with the labor supply of those who do not. This analysis uses variation in housing benefits caused by variation in AFDC benefits to test the effects of housing assistance. Second, it compares the labor supply of households before and after entering housing assistance. Neither of these analyses can quantify the overall effect of housing assistance on labor supply in the way that the approaches discussed above attempt to, but they can identify specific parts of that effect in ways that avoid the vulnerabilities of those approaches.

\section{Effects of Housing Subsidy Receipt on Labor Supply of AFDC Recipients}

A simple comparison of the labor supply of housing subsidy recipients with that of the rest of the population would have little meaning. Eligibility for subsidies is determined by income, and income would be expected to correlate closely with hours worked and labor force participation. As a result, such a comparison would be unable to determine whether labor supply changes were the cause or the effect of program participation.

Because, however, the AFDC eligibility rules were (and TANF rules are) more restrictive than those for housing subsidies, nearly all AFDC recipients were potentially eligible for housing assistance. Many AFDC households would have chosen to go on housing assistance if they could have, and they were unsubsidized only because of rationing. Differences in labor supply were probably not the major reason that some AFDC participants received housing assistance and others did not, so it becomes more plausible to attribute any differences in labor supply to effects of the housing programs.

The analysis here uses data from the Panel Survey on Income Dynamics (PSID) between 1986 and 1992. During this time period, the housing subsidy program rules were very similar to the rules today. The full sample includes 1,620 observations of 555 single women ages 25 to 49 whose households received AFDC benefits at some point during the preceding year. These data are used in two types of analyses, linear regressions with annual hours worked by individuals as 
the dependent variable (labeled " $1 \mathrm{~A}$ " through " $6 \mathrm{~A}$ " in the results) and logistic regressions with labor force participation as the dependent variable (labeled "1B" through " $6 \mathrm{~B}$ " in the results). All regressions include state and year fixed effects, individual and household characteristics, and several program participation variables. Results are shown in Tables IIA-IID.

Regressions $1 \mathrm{~A}$ and $1 \mathrm{~B}$ include housing subsidy receipt as an independent variable. They find subsidy receipt to have substantial, highly significant effects, with coefficients of -125 on annual hours worked and -0.25 on labor force participation.

Although all AFDC recipients, whether or not they received housing benefits, had to have very low earnings, housing recipients and nonrecipients could be

TABLE IIA

Results of Analyses of Labor Supply among AFDC Recipients

\begin{tabular}{lccc}
\hline & $1 \mathrm{~A}$ & $2 \mathrm{~A}$ & $3 \mathrm{~A}$ \\
& $(1986-1992)$ & $(1988-1992)$ & $(1988-1992)$ \\
\hline Constnat & 933.799 & 685.830 & 777.576 \\
Age & $(151.555)$ & $(178.598)$ & $(177.624)$ \\
& 10.597 & 10.455 & 11.042 \\
Black & $(3.153)$ & $(3.683)$ & $(3.645)$ \\
& -107.176 & 5.648 & 28.354 \\
Hispanic & $(58.120)$ & $(67.367)$ & $(66.786)$ \\
& -283.520 & -329.170 & -302.859 \\
More than 12 years of education & $(129.055)$ & $(144.260)$ & $(142.774)$ \\
& 156.407 & 149.218 & 142.656 \\
Fewer than 12 years of education & $(55.282)$ & $(61.278)$ & $(60.618)$ \\
Number of children in household & -116.947 & -142.856 & -120.153 \\
& $(40.947)$ & $(44.639)$ & $(44.390)$ \\
Number of children under 6 in household & -31.151 & -25.189 & -17.494 \\
& $(17.601)$ & $(20.258)$ & $(20.096)$ \\
Residence in a Metropolitan Statistical Area & -7.734 & -4.696 & -12.983 \\
In household that received Food Stamps & $(21.476)$ & $(24.430)$ & $(24.221)$ \\
In household in which someone was covered & -34.127 & -16.445 & -16.491 \\
by Medicaid & $(10.928)$ & $(12.915)$ & $(12.773)$ \\
In household that received housing assistance & -201.608 & -210.654 & -176.556 \\
How many of previous 2 years in household & $(60.029)$ & $(72.078)$ & $(71.624)$ \\
receiving AFDC & $(424.755)$ & $(54.585)$ & -325.539 \\
\hline
\end{tabular}

Note. State and year fixed effects are included in the regressions but are not shown in the table. Linear regression. Dependent variable: annual hours worked, Single females ages 25 to 49 in households that have received AFDC benefits during the previous year: 1986-1992, $N=1620$; 1988-1992, $N=1171$. Unstandardized coefficients. Standard errors in parentheses. 
TABLE IIB

Results of Analyses of Labor Supply among AFDC Recipients

\begin{tabular}{|c|c|c|c|}
\hline & $\begin{array}{c}4 \mathrm{~A} \\
(1986-1992)\end{array}$ & $\begin{array}{c}5 \mathrm{~A} \\
(1988-1992)\end{array}$ & $\begin{array}{c}\text { 6A } \\
(1988-1992)\end{array}$ \\
\hline Constant & $\begin{array}{l}1086.145 \\
(247.632)\end{array}$ & $\begin{array}{c}880.219 \\
(335.042)\end{array}$ & $\begin{array}{c}967.041 \\
(331.922)\end{array}$ \\
\hline Age & $\begin{array}{l}10.141 \\
(3.157)\end{array}$ & $\begin{array}{c}9.757 \\
(3.689)\end{array}$ & $\begin{array}{l}10.358 \\
(3.652)\end{array}$ \\
\hline Black & $\begin{array}{r}-127.002 \\
(58.664)\end{array}$ & $\begin{array}{l}-7.111 \\
(68.132)\end{array}$ & $\begin{array}{c}15.758 \\
(67.564)\end{array}$ \\
\hline Hispanic & $\begin{array}{r}-256.230 \\
(129.273)\end{array}$ & $\begin{array}{r}-318.290 \\
(144.984)\end{array}$ & $\begin{array}{r}-292.573 \\
(143.522)\end{array}$ \\
\hline More than 12 years of education & $\begin{array}{l}173.182 \\
(55.475)\end{array}$ & $\begin{array}{l}165.651 \\
(61.635)\end{array}$ & $\begin{array}{l}158.558 \\
(60.989)\end{array}$ \\
\hline Fewer than 12 years of education & $\begin{array}{r}-107.670 \\
(40.935)\end{array}$ & $\begin{array}{r}-134.102 \\
(44.562)\end{array}$ & $\begin{array}{r}-112.291 \\
(44.312)\end{array}$ \\
\hline Number of children in household & $\begin{array}{c}34.613 \\
(36.354)\end{array}$ & $\begin{array}{c}48.519 \\
(43.508)\end{array}$ & $\begin{array}{c}52.269 \\
(43.047)\end{array}$ \\
\hline Number of children under 6 in household & $\begin{array}{r}-12.746 \\
(21.485)\end{array}$ & $\begin{array}{c}-10.484 \\
(24.412)\end{array}$ & $\begin{array}{l}-18.390 \\
(24.205)\end{array}$ \\
\hline Residence in a Metropolitan Statistical Area & $\begin{array}{r}-37.599 \\
(10.992)\end{array}$ & $\begin{array}{r}-19.367 \\
(13.012)\end{array}$ & $\begin{array}{c}-19.351 \\
(12.872)\end{array}$ \\
\hline In household that received Food Stamps & $\begin{array}{r}-213.910 \\
(59.941)\end{array}$ & $\begin{array}{r}-220.236 \\
(71.758)\end{array}$ & $\begin{array}{r}-185.701 \\
(71.344)\end{array}$ \\
\hline $\begin{array}{l}\text { In household in which someone was covered } \\
\text { by Medicaid }\end{array}$ & $\begin{array}{r}-318.400 \\
(44.638)\end{array}$ & $\begin{array}{r}-348.802 \\
(54.417)\end{array}$ & $\begin{array}{r}-323.876 \\
(54.077)\end{array}$ \\
\hline $\begin{array}{l}\text { How many of previous } 2 \text { years in household } \\
\text { receiving AFDC }\end{array}$ & & & $\begin{array}{r}-133.915 \\
\quad(27.683)\end{array}$ \\
\hline Maximum AFDC benefit & $\begin{array}{r}-0.504 \\
(0.438)\end{array}$ & $\begin{array}{r}-0.511 \\
(0.528)\end{array}$ & $\begin{array}{r}-0.495 \\
(0.522)\end{array}$ \\
\hline $\begin{array}{l}\text { Maximum AFDC benefit multiplied by } \\
\text { housing participation }\end{array}$ & $\begin{array}{c}0.414 \\
(0.196)\end{array}$ & $\begin{array}{c}0.269 \\
(0.222)\end{array}$ & $\begin{array}{c}0.268 \\
(0.220)\end{array}$ \\
\hline $\begin{array}{l}\text { Number of kids multiplied by housing } \\
\text { participation }\end{array}$ & $\begin{array}{r}-107.827 \\
(28.648)\end{array}$ & $\begin{array}{r}-115.961 \\
(32.791)\end{array}$ & $\begin{array}{r}-108.852 \\
(32.471)\end{array}$ \\
\hline
\end{tabular}

Note. State and year fixed effects are included in the regressions but are not shown in the table. Linear regression. Dependent variable: annual hours worked, Single females ages 25 to 49 in households that have received AFDC benefits during the previous year: 1986-1992, $N=1620$; $1988-1992, N=1171$. Unstandardized coefficients. Standard errors in parentheses.

expected to differ in how long they have been in poverty. FHA recipients would have to have been eligible for their area waiting lists for some period of time, while other AFDC recipients could have become poor only recently. Since there may be a correlation between length of time in poverty and labor supply, this difference could account for some of the effects in 1A and 1B.

To attempt to control for length of time in poverty, I included a variable that indicates whether an individual had been in a household that received AFDC for 0,1 , or 2 of the previous 2 years. Because of data limitations, this analysis only 
TABLE IIC

Results of Analyses of Labor Supply among AFDC Recipients

\begin{tabular}{|c|c|c|c|}
\hline & $\begin{array}{c}1 \mathrm{~B} \\
(1986-1992)\end{array}$ & $\begin{array}{c}\text { 2B } \\
(1988-1992)\end{array}$ & $\begin{array}{c}3 \mathrm{~B} \\
(1988-1992)\end{array}$ \\
\hline Constant & $\begin{array}{c}1.4600 \\
(0.5197)\end{array}$ & $\begin{array}{c}0.3532 \\
(0.6285)\end{array}$ & $\begin{array}{c}0.5827 \\
(0.6376)\end{array}$ \\
\hline Age & $\begin{array}{c}0.0079 \\
(0.0110)\end{array}$ & $\begin{array}{c}0.0105 \\
(0.0132)\end{array}$ & $\begin{array}{c}0.0126 \\
(0.0133)\end{array}$ \\
\hline Black & $\begin{array}{c}-0.4502 \\
(0.1974)\end{array}$ & $\begin{array}{r}-0.1452 \\
(0.2348)\end{array}$ & $\begin{array}{r}-0.0780 \\
(0.2376)\end{array}$ \\
\hline Hispanic & $\begin{array}{r}-0.7367 \\
(0.4565)\end{array}$ & $\begin{array}{r}-1.0361 \\
(0.5751)\end{array}$ & $\begin{array}{r}-0.9465 \\
(0.5746)\end{array}$ \\
\hline More than 12 years of education & $\begin{array}{c}0.4958 \\
(0.1874)\end{array}$ & $\begin{array}{c}0.5284 \\
(0.2116)\end{array}$ & $\begin{array}{c}0.5167 \\
(0.2132)\end{array}$ \\
\hline Fewer than 12 years of education & $\begin{array}{r}-0.5397 \\
(0.1426)\end{array}$ & $\begin{array}{r}-0.5580 \\
(0.1597)\end{array}$ & $\begin{array}{r}-0.4969 \\
(0.1617)\end{array}$ \\
\hline Number of children in household & $\begin{array}{c}-0.0221 \\
(0.0606)\end{array}$ & $\begin{array}{c}-0.0242 \\
(0.0714)\end{array}$ & $\begin{array}{c}-0.0013 \\
(0.0721)\end{array}$ \\
\hline Number of children under 6 in household & $\begin{array}{c}-0.1513 \\
(0.0747)\end{array}$ & $\begin{array}{c}-0.1909 \\
(0.0874)\end{array}$ & $\begin{array}{c}-0.2199 \\
(0.0887)\end{array}$ \\
\hline Residence in a Metropolitan Statistical Area & $\begin{array}{r}-0.1143 \\
(0.0390)\end{array}$ & $\begin{array}{r}-0.0989 \\
(0.0471)\end{array}$ & $\begin{array}{r}-0.1015 \\
(0.0472)\end{array}$ \\
\hline In household that received Food Stamps & $\begin{array}{r}-0.0139 \\
(0.2070)\end{array}$ & $\begin{array}{c}0.0008 \\
(0.2568)\end{array}$ & $\begin{array}{c}0.1095 \\
(0.2625)\end{array}$ \\
\hline $\begin{array}{l}\text { In household in which someone was covered } \\
\text { by Medicaid }\end{array}$ & $\begin{array}{r}-0.7742 \\
(0.1531)\end{array}$ & $\begin{array}{r}-0.8942 \\
(0.1931)\end{array}$ & $\begin{array}{r}-0.8314 \\
(0.1954)\end{array}$ \\
\hline In household that received housing assistance & $\begin{array}{c}-0.2546 \\
(0.1265)\end{array}$ & $\begin{array}{r}-0.3837 \\
(0.1506)\end{array}$ & $\begin{array}{r}-0.3349 \\
(0.1518)\end{array}$ \\
\hline $\begin{array}{l}\text { How many of previous } 2 \text { years in household } \\
\text { receiving AFDC }\end{array}$ & & & $\begin{array}{r}-0.3899 \\
(0.0985)\end{array}$ \\
\hline
\end{tabular}

Note. State and year fixed effects are included in the regressions but are not shown in the table. Logistic regression. Depeendent variable: labor force participation, Single females ages 25 to 49 in households that have received AFDC benefits during the previous year: 1986-1992, $N=1620$; $1988-1992, N=1171$. Unstandardized coefficients. Standard errors in parentheses.

included observations between 1988 and 1992. Regressions 2A and 2B, which do not include this years-on-AFDC variable, show that this 5-year group had a somewhat higher coefficient on FHA participation than the 7-year sample. In 3A and $3 \mathrm{~B}$, the years-on-AFDC variable did have a strong negative effect on hours and participation, but even with its inclusion the coefficient on FHA remained large and highly significant.

These results do not rule out the possibility that some factor other than FHA program effects causes the differences in labor supply. It may, for example, be that federal housing subsidy preferences, which were in place throughout this period, selected people to receive housing assistance who tended to have lower 
TABLE IID

Results of Analyses of Labor Suppply among AFDC Recipients

\begin{tabular}{lccc}
\hline & $4 \mathrm{~B}$ & $5 \mathrm{~B}$ & $6 \mathrm{~B}$ \\
& $(1986-1992)$ & $(1988-1992)$ & $(1988-1992)$ \\
\hline Constant & 2.3528 & 1.2008 & 1.4155 \\
Age & $(0.8666)$ & $(1.2380)$ & $(1.2462)$ \\
& 0.0057 & 0.0065 & 0.0086 \\
Black & $(0.0111)$ & $(0.0133)$ & $(0.0134)$ \\
& -0.5093 & -0.1839 & -0.1162 \\
Hispanic & $(0.2005)$ & $(0.2389)$ & $(0.2416)$ \\
& -0.6717 & -1.0104 & -0.9286 \\
More than 12 years of education & $(0.4588)$ & $(0.5789)$ & $(0.5796)$ \\
& 0.5732 & 0.6176 & 0.6036 \\
Fewer than 12 years of education & $(0.1901)$ & $(0.2165)$ & $(0.2182)$ \\
& -0.5066 & -0.5234 & -0.4652 \\
Number of children in household & $(0.1436)$ & $(0.1610)$ & $(0.1630)$ \\
Number of children under 6 in household & 0.2407 & 0.2315 & 0.2464 \\
Residence in a Metropolitan Statistical Area & $(0.1254)$ & $(0.1543)$ & $(0.1557)$ \\
In household that received Food Stamps & -0.1727 & -0.2162 & -0.2440 \\
In household that someone was covered & $(0.0754)$ & $(0.0886)$ & $(0.0898)$ \\
by Medicaid & -0.1319 & -0.1141 & -0.1164 \\
How many of previous 2 years in household & $(0.0400)$ & $(0.0485)$ & $(0.0486)$ \\
receiving AFDC & -0.0445 & -0.0163 & 0.0929 \\
Maximum AFDC benefit & $(0.2077)$ & $(0.2579)$ & $(0.2639)$ \\
Maximum AFDC benefit multiplied by & -0.7684 & -0.8901 & -0.8301 \\
housing participation & & $(0.1941)$ & $(0.1964)$ \\
Number of kids multiplying by housing & -0.0024 & -0.0020 & -0.0019 \\
participation & $(0.0015)$ & $(0.0019)$ & $(0.0019)$ \\
\hline & 0.0016 & 0.0013 & 0.0013 \\
& $(0.0007)$ & $(0.0008)$ & $(0.0008)$ \\
& -0.3670 & -0.4158 & -0.4002 \\
& $(0.1017)$ & $(0.1223)$ & $(0.1229)$ \\
\hline
\end{tabular}

Note. State and year fixed effects are inclouded in the regressions but are not shown in the table. Logistic regression. Dependent variable: labor force participation, Single females ages 25 to 49 in households that have received AFDC benefits during the previous year: 1986-1992, $N=1620$; $1988-1992, N=1171$. Unstandardized coefficients. Standard errors in parentheses.

labor supply. It is also possible that the variables included in $3 \mathrm{~A}$ and $3 \mathrm{~B}$ did not fully control for the effects of length of time in poverty.

As a further test to determine whether the coefficients on FHA are actually an effect of the program, I included the variation in FHA subsidy size created by variation in AFDC benefits in the analysis. As discussed earlier, under both TANF and AFDC welfare benefits have been counted as income in the formula used to determine the size of housing subsidies. Since households have been required to contribute $30 \%$ of their income to rent, holding all else constant, 
every $\$ 1.00$ increase in the maximum welfare benefits would reduce the maximum housing subsidy by $\$ 0.30$.

During the period examined, AFDC benefits varied widely over time and from state to state. In 1986, for example, benefits for a family of three ranged from $\$ 118$ a month in Alabama to $\$ 617$ a month in California. By 1992, benefits in those states had risen to $\$ 164$ and $\$ 624$, respectively. There was not, however, substantial variation in benefit reduction rates (BRRs). Throughout this period, recipients faced a $67 \%$ BRR during the first four months they worked while on welfare, and a $100 \%$ BRR if they worked more than four consecutive months while on aid. In addition, a small amount of earnings was not deducted from benefits. This "earnings disregard" was raised by $\$ 15$ in 1988, but was otherwise held constant.

Without variation in BRRs, welfare benefits have no effect on the housing subsidy marginal tax. An AFDC recipient facing a $67 \%$ benefit reduction rate would see her housing subsidy fall by $\$ 0.10$ for every dollar her earnings rose, regardless of how large the AFDC benefit was. Similarly, all AFDC recipients facing $100 \%$ BRRs would receive a constant subsidy as their earnings rose, since their countable incomes would not increase at all until their AFDC benefits had been reduced to zero.

Variation in AFDC benefits should, however, alter the size of the income effect of the housing subsidy. In areas and years where housing benefits are larger, the difference in ability to get by with low reported earnings between households with and without benefits would be greater, and the gap in labor supply would be expected to be wider as well.

Using variation in AFDC benefits has several advantages over using variation in FMRs. First, while FMRs are determined by federal formulas based on the housing costs faced by low-income families, AFDC benefits are the result of state political processes. While political outcomes may be correlated with social and economic conditions that are in turn correlated with labor supply, it is probable that the inclusion of state fixed effects variables can control adequately for these links (see, for example, Hoynes, 1997).

Furthermore, a change in the AFDC grant has a direct impact on the budgets of subsidized households relative to unsubsidized households. Regardless of the value it places on its housing subsidy, a household that receives an additional $\$ 100$ from AFDC will have to contribute \$30 more in cash toward its rent. Using the AFDC benefit avoids estimating a value for public housing units, determining the fungibility of subsidies, or identifying what portion of a larger FMR reflects a larger amount of housing consumption.

In addition, while this analysis cannot attempt to measure the effects of rationing, neither is it vulnerable to distortions resulting from rationing. Its scope is limited to the income effects of households actually receiving housing subsidies, so the proportion of households who are subsidized would not affect the outcome.

To test the relationship between AFDC benefit levels and housing subsidy 
effects, I added three variables to $4 \mathrm{~A}$ and $4 \mathrm{~B}$. The first of these was the maximum AFDC benefit for an individual based on number of children, state, and year. The second was the number of children multiplied by the FHA participation dummy variable. This was intended to control for the fact that both FHA and AFDC benefits are higher for larger families. The third variable was the size of the AFDC guarantee multiplied by the FHA dummy variable. A positive coefficient on this third variable would indicate that the negative impact of housing subsidies on labor supply falls as rising AFDC benefits reduce the size of the maximum subsidy.

The regression results from both the hours and the participation analyses show positive coefficients on the interaction between FHA participation and AFDC benefits, significant at the 0.10 level. These coefficients suggest that the $\$ 30$ dollar cut in the monthly housing subsidy that would result from a $\$ 100$ increase in the maximum AFDC benefit would be linked to a $16 \%$ rise in labor force participation and an increase of 41 in annual hours worked among welfare recipients who also receive housing assistance.

In $5 \mathrm{~A}$ and $5 \mathrm{~B}$, which use the smaller, 5-year sample that I used above for the years-on-AFDC analysis but do not include the years-on-AFDC variable, the coefficients on the FHA participation and AFDC benefit interaction are of roughly the same magnitude, but they are not significant at conventional levels. The inclusion of the years-on-AFDC variable in $6 \mathrm{~A}$ and $6 \mathrm{~B}$ has almost no effect on these coefficients. ${ }^{4}$

One key assumption here is that there is not a correlation between AFDC benefits and FMRs that is not controlled for in the analysis. State and year fixed effect variables are included in the regressions, so only a trend that involves an interaction between states and years would be problematic. Since the sources of the decisions that set benefits and FMRs are so different, this seems a reasonable assumption, but it is possible that a correlation exists that would distort the findings.

Another possible source of bias is the likelihood that an increase in the maximum AFDC benefit would change the composition of both the AFDC and the AFDC/FHA populations. Raising the maximum benefit, while leaving the BRR the same, would increase the earnings level at which benefits are cut off. Some households with earnings between the old and the new cutoffs would choose to go on aid, and some with even higher earnings might lower their labor supply enough that they would become eligible. However, while it would be likely that the new recipients would have higher overall labor supply than the previous

\footnotetext{
${ }^{4}$ As an additional test, all of the regressions described above were rerun with individual fixed effects added to the analyses. The magnitudes of all effects were reduced substantially and their statistical significance was eliminated, but in all cases the effects continued to be in the same direction as those detected without the individual fixed effects.
} 
recipients, there does not seem to be a strong reason to expect that the new recipients would be less affected by receipt of housing assistance.

Finally, the simple increase in income from an AFDC benefit increase may reduce the impact of FHA receipt on labor supply independent of any effect on the size of the FHA benefit. Even a constant FHA benefit would make up a smaller proportion of a family's income, and perhaps that would lead to a weaker effect. If this were the case, a portion of the effect identified would not be attributable to variation in the housing subsidy.

On the whole, however, variation in the housing subsidy appears to be the strongest explanation for the identified effect. This suggests that housing subsidies have a substantial income effect on the labor supply of AFDC recipients. While it is possible, there does not seem to be a clear reason to expect that this effect would not extend to other subsidy recipients.

\section{Comparison of Labor Supply before and after Beginning Receipt of Housing Assistance}

The second analysis compares the labor supply of individuals during the year before their households go on housing assistance with the labor supply of those same individuals during the latest year for which data is available after their households begin receiving aid. The sample is again drawn from the PSID between 1986 and 1992, and it includes 425 individuals ages 25 to 49 .

As with the first analysis, this comparison is made meaningful by the rationing of housing subsidies. A simple before-and-after comparison of labor supply by households beginning receipt of Food Stamps or TANF could not show labor supply effects of those programs because households are able to receive aid almost immediately after their incomes become low enough to meet eligibility limits. It would, again, be unclear whether lower labor supply allowed households to go on aid or the prospect of going on aid induced households to lower their labor supply.

By contrast, households that receive housing assistance would not go on aid immediately after becoming eligible. They would meet the very low-income eligibility requirement, go on a waiting list for some period of time, and then begin to receive aid. It would be expected that both exogenous labor supply changes that allowed households to become eligible and labor supply decisions made in response to the very low-income eligibility limit would occur at the point when the household went on the waiting list. Changes in labor supply at the point where a household actually went on housing aid could be attributed to the income effect of the total subsidy, to the subsidy marginal tax, and to the removal of the very low-income limit required for entry into the subsidy programs. The income and marginal tax effects would be expected to reduce labor supply, while the removal of the income limit would be expected to raise labor supply.

Overall, annual hours worked among this sample fell by 59 hours after they 
went on aid, while labor force participation fell by $5.4 \%$. Results are shown in Tables IIIA and IIIB. Women and single men experienced declines in both hours worked and participation, while married men worked the same number of hours and had higher participation rates. Of these findings, the changes in participation among the population as a whole and among single men were statistically significant at a level of 0.10 .

Other trends in the characteristics and circumstances of individuals occurred at the same time as the transition onto housing assistance. All individuals were older and living in a later year at the time of the after-going-on-aid measurement. In addition, individuals overall tended to have more education and more children, and they tended to participate in more public assistance programs after going on housing assistance than before.

In order to control for these differences, all of which could be expected to affect labor supply, additional analyses were carried out using parameters based on the effects associated with these factors in a larger sample. Parameters were based on regression coefficients on each characteristic in an analysis of individuals aged 25 to 49 in the PSID sample from 1986 to $1992 .{ }^{5}$ Since it could be expected that low-income individuals experience different parameters than the population as a whole, the analysis used to set the parameters was limited to those whose household participated in housing assistance, AFDC, Medicaid, or Food Stamps at some point during the 7 years examined.

TABLE IIIA

Before and after Comparison Results: Annual Hours Worked

\begin{tabular}{|c|c|c|c|c|c|}
\hline $\begin{array}{l}\text { Gender and } \\
\text { marital status }\end{array}$ & $\begin{array}{l}\text { Number of } \\
\text { individuals }\end{array}$ & $\begin{array}{c}\text { Hours } 2 \\
\text { years } \\
\text { before } \\
\text { going } \\
\text { on aid }\end{array}$ & $\begin{array}{l}\text { Change in } \\
\text { actual hours } \\
\text { from year } \\
\text { before aid } \\
\text { to last } \\
\text { observation } \\
\text { after going } \\
\text { on aid (s.e.) }\end{array}$ & $\begin{array}{l}\text { Change in hours } \\
\text { from year before aid } \\
\text { to last observation } \\
\text { after going on aid } \\
\text { parameterized using } \\
\text { public assistance } \\
\text { recipients (s.e.) }\end{array}$ & $\begin{array}{l}\text { Change in hours } \\
\text { from year before } \\
\text { aid to last } \\
\text { observation after } \\
\text { going on aid } \\
\text { parameterized } \\
\text { using full } \\
\text { sample (s.e.) }\end{array}$ \\
\hline Single female & 150 & $1022(78)$ & $-102(108)$ & $-169(95)$ & $-112(92.9)$ \\
\hline Married female & 87 & $1128(95)$ & $-94(138)$ & $-43(171)$ & $-35(132)$ \\
\hline Single male & 94 & $1225(103)$ & $-70(147)$ & $-76(135)$ & $-70(130)$ \\
\hline Married male & 94 & $1881(82)$ & $53(120)$ & 96 (109) & 86 (107) \\
\hline All & 425 & 1279 (47) & $-59(68)$ & $-64(67)$ & $-43(59)$ \\
\hline
\end{tabular}

${ }^{5}$ In order to test the statistical validity of the parameters, a set of parameters in each gender/marital status category was calculated using one half of the sample. The "predicted" parameters based on this analysis were then compared with the actual parameters identified in the other half of the population, and an $f$-test was used to determine whether the hypothesis that they were from the same population could be disproved. $F$-scores ranged from 1.00 to 1.34 , well below the score of 1.86 that would have been required to rule out identical populations at the 0.10 level. See Lapham (1971). 
TABLE IIIB

Before and after Comparison Results: Labor Force Participation

\begin{tabular}{|c|c|c|c|c|c|}
\hline $\begin{array}{l}\text { Gender and } \\
\text { marital status }\end{array}$ & $\begin{array}{l}\text { Number of } \\
\text { individuals }\end{array}$ & $\begin{array}{l}\text { Labor force } \\
\text { participation } \\
\text { two years } \\
\text { before } \\
\text { going } \\
\text { on aid }\end{array}$ & $\begin{array}{c}\text { Change in } \\
\text { actual } \\
\text { participation } \\
\text { from year } \\
\text { before aid } \\
\text { to last } \\
\text { observation } \\
\text { after going } \\
\text { on aid (s.e.) }\end{array}$ & $\begin{array}{l}\text { Change in } \\
\text { participation } \\
\text { from year before } \\
\text { aid to last } \\
\text { observation } \\
\text { after going on aid } \\
\text { parameterized } \\
\text { using public } \\
\text { assistance } \\
\text { recipients (s.e.) }\end{array}$ & $\begin{array}{c}\text { Change in } \\
\text { participation } \\
\text { from year before } \\
\text { aid to last } \\
\text { observation } \\
\text { after } \\
\text { going on aid } \\
\text { parameterized } \\
\text { using full } \\
\text { sample (s.e.) }\end{array}$ \\
\hline Single female & 150 & $69.3 \%$ & $\begin{array}{r}-2.7 \% \\
(5.4 \%)\end{array}$ & $\begin{array}{r}-28.1 \% \\
(18.8 \%)\end{array}$ & $\begin{array}{r}-13.5 \% \\
(14.2 \%)\end{array}$ \\
\hline Married female & 87 & $78.2 \%$ & $\begin{array}{c}-9.2 \% \\
(6.7 \%)\end{array}$ & $\begin{array}{c}-11.9 \% \\
(12.5 \%)\end{array}$ & $\begin{array}{c}2.9 \% \\
(14.1 \%)\end{array}$ \\
\hline Single male & 94 & $77.7 \%$ & $\begin{array}{r}-11.7 \% \\
(6.5 \%)\end{array}$ & $\begin{array}{c}-10.2 \% \\
(18.5 \%)\end{array}$ & $\begin{array}{l}-4.8 \% \\
(23.7)\end{array}$ \\
\hline Married male & 94 & $93.6 \%$ & $\begin{array}{c}0.0 \% \\
(3.6 \%)\end{array}$ & $\begin{array}{c}35.5 \% \\
(22.7 \%)\end{array}$ & $\begin{array}{c}33.0 \% \\
(20.2 \%)\end{array}$ \\
\hline All & 425 & $78.4 \%$ & $\begin{array}{c}-5.4 \% \\
(2.9 \%)\end{array}$ & $\begin{array}{l}-6.8 \% \\
(15.4 \%)\end{array}$ & $\begin{array}{c}2.1 \% \\
(11.1 \%)\end{array}$ \\
\hline
\end{tabular}

In all cases, the parameterized labor supply changes were in the same direction as the unparameterized changes, although the magnitudes were sometimes very different. Partly because the standard errors of the differences between parameterized labor force participation rates were about twice as high as those between the unparameterized rates, none of the changes that had been statistically significant in the unparameterized analysis remained significant. Overall, the addition of parameters raised the effect on labor supply from $5.4 \%$ to $6.8 \%$ and the effect on hours from 59 to 64 .

An alternative set of parameters was calculated using the entire PSID sample between ages 25 and 49. This set of parameters altered some results substantially. Most importantly, they changed the signs on labor force participation for married women and for the sample as a whole from negative to positive. It would be expected that the actual parameters for the sample examined here would be closer to those of public assistance recipients than those of the general population, so this result does not necessarily reduce the validity of the findings. Nonetheless, it does illustrate that the finding is sensitive to the methods used to calculate the parameters.

\section{CONCLUSIONS AND POLICY IMPLICATIONS}

The findings of this paper strongly suggest that federal rental subsidies reduce labor supply through income and marginal tax effects on individuals who are 
currently receiving assistance. While the analyses used here give no indication of whether the program affects the labor supply of unsubsidized households, and cannot provide an estimate of the overall impact of the subsidies, they are able to show evidence of labor supply effects while avoiding the most serious vulnerabilities of other analytic methods.

These findings are not surprising. As discussed above, housing subsidies make up a substantial proportion of the incomes of families with very low earnings, and they impose marginal tax rates as high as $30 \%$ on families that often already face very high marginal tax rates.

While labor supply effects probably represent a cost of housing subsidies, this does not in itself mean that something is wrong with the program. For most means tested benefits, changing the program characteristics that appear to deter work, such as the marginal tax rate, involves difficult trade-offs. Absent increased public spending to allow a more gradual phase out, marginal tax rates can only be reduced by cutting maximum benefits, usually those received by the poorest families. Furthermore, the marginal tax rates of the housing program are not strikingly high when compared with those of other means tested programs. All but a few state TANF programs, for example, cut benefits at rates more rapid than the $30 \%$ used in the rental subsidy programs. The findings of this paper do not necessarily lead to the conclusion that the benefits of reducing marginal tax rates would be worth reducing maximum housing subsidies, or that housing subsidy marginal tax rates are any more harmful than those of other programs.

What does, however, distinguish housing assistance from most other means tested benefit programs is the rationing of subsidies. Rationing concentrates both benefits and marginal taxes on some eligible families and denies assistance to other, sometimes equally needy, families. A more broadly distributed subsidy could both cut the marginal tax rates experienced by participants and extend assistance to many additional families, without changing the income level at which benefits are cut off or increasing program costs.

Federal housing subsidies reach about $30 \%$ of poor renters nationally (Susin, 1997), and, to give one example, push the total marginal tax rate faced by a Philadelphia family of three to $87 \%$ as its monthly earnings rise from $\$ 1000$ to $\$ 2000$. A universal subsidy $70 \%$ smaller than the current benefit could reach an additional $70 \%$ of low-income renters and reduce the overall marginal tax rate in the example to $60 \%$ while maintaining program costs at approximately their current level. It is, however, unlikely that $100 \%$ of low-income renters would actually utilize this housing benefit. A more incremental broadening that cut subsidies by $25 \%$, again roughly cost-neutral, could subsidize an additional $10 \%$ of low-income renters and reduce the total marginal tax rate for the Philadelphia family by $6 \%$.

Under this type of policy change, the reduction in earnings disincentives among participants would be at least partially offset by an increase in disincentives among families to whom new benefits were extended. ${ }^{6}$ Extension of benefits to 
a larger proportion of those eligible could also either lengthen or shorten waiting lists (see Lindsay and Feigenbaum, 1984), with accompanying effects on both labor supply and family well-being. Nonetheless, a broadening of subsidies would certainly increase the number of needy families assisted and reduce the number of families exposed to the most extreme distortions of earnings incentives, and it would probably also reduce the overall effect of subsidies on labor supply.

${ }^{6}$ Concentrated benefits would probably result in greater overall earning disincentives than dispersed benefits if a change in the marginal tax of the same magnitude would have a greater effect on earnings at higher than at lower total marginal tax levels. If the households that received the dispersed benefits were affected differently by disincentives than the households who had received the concentrated benefits, this would also affect the relative overall impact on labor supply.

APPENDIX A: 1998 MONTHLY INCOME TABLES FOR A SINGLE PARENT WITH TWO CHILDREN 
TABLE IVA

Dallas, TX

\begin{tabular}{|c|c|c|c|c|c|c|c|c|c|c|c|c|c|c|}
\hline $\begin{array}{l}\text { Maximum TANF } \\
\text { benefit }\end{array}$ & 188 & 2 bedroom & MR & 694 & & & & & & & & & & \\
\hline TANF BRR & 0.667 & Low-incom & limit & 3625 & & & & & & & & & & \\
\hline TANF disregard & 120 & & & & & & & & & & & & & \\
\hline Earnings & 0 & 200 & 400 & 600 & 800 & 1000 & 1200 & 1400 & 1600 & 1800 & 2000 & 2200 & 2400 & 2600 \\
\hline TANF & 188 & 135 & 1 & 0 & 0 & 0 & 0 & 0 & 0 & 0 & 0 & 0 & 0 & 0 \\
\hline Food stamps & 322 & 301 & 310 & 274 & 238 & 202 & 166 & 130 & 0 & 0 & 0 & 0 & 0 & 0 \\
\hline FICA & 0 & -15 & -31 & -46 & -61 & -77 & -92 & -107 & -123 & -138 & -153 & -168 & -184 & -199 \\
\hline EITC & 0 & 81 & 161 & 241 & 313 & 313 & 275 & 233 & 192 & 149 & 107 & 64 & 22 & 0 \\
\hline Housing assistance & 638 & 606 & 598 & 538 & 478 & 418 & 358 & 298 & 238 & 178 & 118 & 58 & 0 & 0 \\
\hline Income with FHA & 1147 & 1307 & 1438 & 1607 & 1768 & 1856 & 1907 & 1948 & 1892 & 1966 & 2037 & 2108 & 2179 & 2326 \\
\hline Marginal tax with FHA & - & $20 \%$ & $34 \%$ & $16 \%$ & $19 \%$ & $56 \%$ & $75 \%$ & $80 \%$ & $128 \%$ & $63 \%$ & $65 \%$ & $65 \%$ & $64 \%$ & $27 \%$ \\
\hline Income without FHA & 517 & 729 & 860 & 1124 & 1352 & 1500 & 1611 & 1712 & 1654 & 1788 & 1919 & 2050 & 2179 & 2326 \\
\hline $\begin{array}{l}\text { Marginal tax without } \\
\text { FHA }\end{array}$ & - & $-6 \%$ & $35 \%$ & $-32 \%$ & $-14 \%$ & $26 \%$ & $45 \%$ & $50 \%$ & $129 \%$ & $33 \%$ & $35 \%$ & $35 \%$ & $35 \%$ & $27 \%$ \\
\hline $\begin{array}{l}\text { Marginal tax incre- } \\
\text { ment from FHA }\end{array}$ & - & $26 \%$ & $-1 \%$ & $48 \%$ & $33 \%$ & $30 \%$ & $30 \%$ & $30 \%$ & $-1 \%$ & $30 \%$ & $30 \%$ & $30 \%$ & $29 \%$ & $0 \%$ \\
\hline
\end{tabular}




\section{TABLE IVB}

Los Angeles, CA

\begin{tabular}{|c|c|c|c|c|c|c|c|c|c|c|c|c|c|c|}
\hline $\begin{array}{l}\text { Maximum TANF } \\
\text { benefit }\end{array}$ & 565 & 2 bedroom & MR & 737 & & & & & & & & & & \\
\hline TANF BRR & 0.5 & Low-incon & limit & 3079 & & & & & & & & & & \\
\hline TANF disregard & 225 & & & & & & & & & & & & & \\
\hline Earnings & 0 & 200 & 400 & 600 & 800 & 1000 & 1200 & 1400 & 1600 & 1800 & 2000 & 2200 & 2400 & 2600 \\
\hline TANF & 565 & 565 & 478 & 378 & 278 & 178 & 78 & 0 & 0 & 0 & 0 & 0 & 0 & 0 \\
\hline Food stamps & 200 & 164 & 154 & 148 & 142 & 138 & 138 & 130 & 0 & 0 & 0 & 0 & 0 & 0 \\
\hline FICA & 0 & -15 & -31 & -46 & -61 & -77 & -92 & -107 & -123 & -138 & -153 & -168 & -184 & -199 \\
\hline EITC & 0 & 81 & 161 & 241 & 313 & 313 & 275 & 233 & 192 & 149 & 107 & 64 & 22 & 0 \\
\hline FHA & 568 & 520 & 498 & 468 & 438 & 408 & 378 & 341 & 281 & 221 & 161 & 101 & 41 & 0 \\
\hline Income with FHA & 1332 & 1514 & 1659 & 1788 & 1909 & 1959 & 1976 & 1991 & 1935 & 2009 & 2080 & 2151 & 2220 & 2326 \\
\hline Marginal tax with FHA & - & $9 \%$ & $28 \%$ & $36 \%$ & $39 \%$ & $75 \%$ & $92 \%$ & $93 \%$ & $128 \%$ & $63 \%$ & $65 \%$ & $65 \%$ & $65 \%$ & $47 \%$ \\
\hline Income without FHA & 840 & 1070 & 1236 & 1395 & 1546 & 1624 & 1665 & 1712 & 1654 & 1788 & 1919 & 2050 & 2179 & 2326 \\
\hline $\begin{array}{l}\text { Marginal tax without } \\
\text { FHA }\end{array}$ & - & $-15 \%$ & $17 \%$ & $21 \%$ & $24 \%$ & $61 \%$ & $80 \%$ & $77 \%$ & $129 \%$ & $33 \%$ & $35 \%$ & $35 \%$ & $35 \%$ & $27 \%$ \\
\hline $\begin{array}{l}\text { Marginal tax incre- } \\
\text { ment from FHA }\end{array}$ & - & $24 \%$ & $11 \%$ & $15 \%$ & $15 \%$ & $14 \%$ & $12 \%$ & $16 \%$ & $-1 \%$ & $30 \%$ & $30 \%$ & $30 \%$ & $29 \%$ & $20 \%$ \\
\hline
\end{tabular}


TABLE IVC

Philadelphia, PA

\begin{tabular}{|c|c|c|c|c|c|c|c|c|c|c|c|c|c|c|}
\hline $\begin{array}{l}\text { Maximum TANF } \\
\text { benefit }\end{array}$ & 421 & 2 bedroom & GMR & 704 & & & & & & & & & & \\
\hline TANF BRR & 0.5 & Low-incom & limit & 3175 & & & & & & & & & & \\
\hline TANF disregard & 0 & & & & & & & & & & & & & \\
\hline Earnings & 0 & 200 & 400 & 600 & 800 & 1000 & 1200 & 1400 & 1600 & 1800 & 2000 & 2200 & 2400 & 2600 \\
\hline TANF & 421 & 321 & 221 & 121 & 21 & 0 & 0 & 0 & 0 & 0 & 0 & 0 & 0 & 0 \\
\hline Food stamps & 243 & 237 & 231 & 231 & 231 & 202 & 166 & 130 & 0 & 0 & 0 & 0 & 0 & 0 \\
\hline FICA & 0 & -15 & -31 & -46 & -61 & -77 & -92 & -107 & -123 & -138 & -153 & -168 & -184 & -199 \\
\hline EITC & 0 & 81 & 161 & 241 & 313 & 313 & 275 & 233 & 192 & 149 & 107 & 64 & 22 & 0 \\
\hline Housing assistance & 578 & 560 & 542 & 512 & 482 & 428 & 368 & 308 & 248 & 188 & 128 & 68 & 8 & 0 \\
\hline Income with FHA & 1242 & 1383 & 1523 & 1658 & 1785 & 1866 & 1917 & 1958 & 1902 & 1976 & 2047 & 2118 & 2187 & 2326 \\
\hline Marginal tax with FHA & - & $29 \%$ & $30 \%$ & $33 \%$ & $36 \%$ & $60 \%$ & $75 \%$ & $80 \%$ & $128 \%$ & $63 \%$ & $65 \%$ & $65 \%$ & $65 \%$ & $31 \%$ \\
\hline Income without FHA & 739 & 899 & 1057 & 1216 & 1367 & 1500 & 1611 & 1712 & 1654 & 1788 & 1919 & 2050 & 2179 & 2326 \\
\hline $\begin{array}{l}\text { Marginal tax without } \\
\text { FHA }\end{array}$ & - & $20 \%$ & $21 \%$ & $21 \%$ & $24 \%$ & $33 \%$ & $45 \%$ & $50 \%$ & $129 \%$ & $33 \%$ & $35 \%$ & $35 \%$ & $35 \%$ & $27 \%$ \\
\hline $\begin{array}{l}\text { Marginal tax incre- } \\
\text { ment from FHA }\end{array}$ & - & $9 \%$ & $9 \%$ & $12 \%$ & $12 \%$ & $27 \%$ & $30 \%$ & $30 \%$ & $-1 \%$ & $30 \%$ & $30 \%$ & $30 \%$ & $30 \%$ & $4 \%$ \\
\hline
\end{tabular}


TABLE IVD

Scranton, PA

\begin{tabular}{|c|c|c|c|c|c|c|c|c|c|c|c|c|c|c|}
\hline $\begin{array}{l}\text { Maximum TANF } \\
\text { benefit }\end{array}$ & 421 & 2 bedroom & $\mathrm{MR}$ & 472 & & & & & & & & & & \\
\hline TANF BRR & 0.5 & Low-incon & limit & 2333 & & & & & & & & & & \\
\hline TANF disregard & 0 & & & & & & & & & & & & & \\
\hline Earnings & 0 & 200 & 400 & 600 & 800 & 1000 & 1200 & 1400 & 1600 & 1800 & 2000 & 2200 & 2400 & 2600 \\
\hline TANF & 421 & 321 & 221 & 121 & 21 & 0 & 0 & 0 & 0 & 0 & 0 & 0 & 0 & 0 \\
\hline Food stamps & 243 & 237 & 231 & 231 & 231 & 202 & 166 & 130 & 0 & 0 & 0 & 0 & 0 & 0 \\
\hline FICA & 0 & -15 & -31 & -46 & -61 & -77 & -92 & -107 & -123 & -138 & -153 & -168 & -184 & -199 \\
\hline EITC & 0 & 81 & 161 & 241 & 313 & 313 & 275 & 233 & 192 & 149 & 107 & 64 & 22 & 0 \\
\hline Housing assistance & 346 & 328 & 310 & 280 & 250 & 196 & 136 & 76 & 16 & 0 & 0 & 0 & 0 & \\
\hline Income with FHA & 1010 & 1151 & 1291 & 1426 & 1553 & 1634 & 1685 & 1726 & 1670 & 1788 & 1919 & 2050 & 2179 & 2326 \\
\hline Marginal tax with FHA & - & $29 \%$ & $30 \%$ & $33 \%$ & $36 \%$ & $60 \%$ & $75 \%$ & $80 \%$ & $128 \%$ & $41 \%$ & $35 \%$ & $35 \%$ & $35 \%$ & $27 \%$ \\
\hline Income without FHA & 739 & 899 & 1057 & 1216 & 1367 & 1497 & 1590 & 1672 & 1654 & 1788 & 1919 & 2050 & 2179 & 2326 \\
\hline $\begin{array}{l}\text { Marginal tax without } \\
\text { FHA }\end{array}$ & - & $20 \%$ & $21 \%$ & $21 \%$ & $24 \%$ & $35 \%$ & $54 \%$ & $59 \%$ & $109 \%$ & $33 \%$ & $35 \%$ & $35 \%$ & $35 \%$ & $27 \%$ \\
\hline $\begin{array}{l}\text { Marginal tax incre- } \\
\text { ment from FHA }\end{array}$ & - & $9 \%$ & $9 \%$ & $12 \%$ & $12 \%$ & $25 \%$ & $21 \%$ & $21 \%$ & $21 \%$ & $9 \%$ & $0 \%$ & $0 \%$ & $0 \%$ & $0 \%$ \\
\hline
\end{tabular}




\section{APPENDIX B: ASSUMPTIONS AND SOURCES FOR BENEFIT AND TAX CALCULATIONS}

\section{Assumptions}

It was assumed that parents are single and not elderly, and that they have two children over two years old. Families were also assumed to spend $10 \%$ of earnings per child on child care, to pay rent equal to the 1998 Fair Market Rent for a two-bedroom apartment, and to have no federal or state income tax liability.

\section{Sources}

Temporary Assistance for Needy Families. 1998 Green Book, U.S. House of Representatives Committee on Ways and Means, 1998.

Food Stamps. 1998 Green Book, U.S. House of Representatives Committee on Ways and Means, 1998. "Food Stamp Eligibility and Benefits For Households in the 48 Contiguous States and the District of Columbia," U.S. Department of Agriculture, Oct. 1998. Telephone interview, U.S. Department of Agriculture staff, Nov. 1, 1999.

Earned Income Tax Credits. " 1998 Earned Income Credit Table and Instructions," Internal Revenue Service. 1998 Green Book, U.S. House of Representatives Committee on Ways and Means, 1998.

FICA. "Urban Institute State TANF Income Calculator," http://new federalism.urban.org, Nov. 3, 1998.

Federal Housing Assistance. "How TTP is Determined," Berkeley Housing Authority, 1998. 1998 Green Book, U.S. House of Representatives Committee on Ways and Means, 1998. Federal Register, 62:187, Sept. 26, 1997, p. 50731. G. Painter, "Low-Income Housing Assistance: Its Impact on Labor Force and Housing Program Participation," http://www-rcf.usc.edu/ gpainter/housing.htm, 1997. Telephone interview, U.S. Department of Housing and Urban Development staff, June 15, 1999. http://www.huduser.org/datasets/il/fmr98/allstate/.txt, June 7, 1999.

\section{REFERENCES}

Besley, T., and Case, A. (1994). "Unnatural Experiments? Estimating the Incidence of Endogenous Policies," Working Paper 4956. Cambridge, MA: National Bureau of Economic Research.

Blank, R. (1985). "The Impact of State Economic Differentials on Household Welfare and Labor

Force Behavior," J. Public Econ. 28, 25-58.

Blinder, A., and Rosen, H. (1985). "Notches," Amer. Econ. Rev. 75, 736-747. 
Cullis, J., and Jones, P. (1984). "Rationing by Waiting Lists: An Implication," Amer. Econ. Rev. 74, 404-417.

Currie, J., and Yelowitz, A. (1998). "Public Housing and Labor Supply,” Working Paper 8. Chicago: Joint Center for Poverty Research.

Danziger, S. et al., (1992). "Work and Welfare as Determinants of Female Poverty and Household Headship," Quart. J. Econ., 519-534.

Edin, K., and Lein, L. (1997). Making Ends Meet: How Single Mothers Survive Welfare and LowWage Work. New York: Russell Sage Foundation.

Hoynes, H. (1997). "Does Welfare Play Any Role in Female Headship Decisions?" J. Public Econ. 65, 89-117.

Keene, M., and Moffitt, R. (1998). "A Structural Model of Multiple Welfare Program Participation and Labor Supply," Int. Econ. Rev. 39, 553-589.

Lapham, V. (1971). “Do Blacks Pay More for Housing?” J. Polit. Econ. 79, 1244-1257.

Lindsay, C., and Feigenbaum, B. (1984). "Rationing by Waiting Lists," Amer. Econ. Rev. 74, 404-417. Mayo, S. (1983). "Benefits from Subsidized Housing," in The Great Housing Experiment (J. Friedman and D. Weinberg, Eds.), pp. 235-257. Beverly Hills: Sage.

Moffitt, R. (1989). "Estimating the Value of an In Kind Transfer: The Case of Food Stamps," Econometrical 57, 385-409.

Moffitt, R. (1992). "Incentive Effects of the U.S. Welfare System: A Review," J. Econ. Lit. 30, 1-61.

Nelson, K., and Khadduri, J. (1992). "To Whom Should Limited Housing Resources Be Directed?" Housing Pol. Debate 3(1), 1-55.

Olsen, E., (1983). "Benefits from Subsidized Housing," in The Great Housing Experiment (J. Friedman and D. Weinberg, Eds.), pp. 266-275. Beverly Hills: Sage.

Painter, G. (1997). "Low-Income Housing Assistance: Its Impact on Labor Force and Housing Program Participation," working paper, http://www-rcf.usc.edu/ gpainter/housing.htm.

Susin, S. (1997). "Housing the Poor: Rent Vouchers and the Price of Low-Income Housing," working paper, University of California Berkeley.

U.S. Department of Housing and Urban Development (1998). "A Picture of Subidized Housing," http://www.huduser.org/datasets/assthsg/statedata98/descript.html.

U.S. Government Printing Office (1997). Federal Register, 62:187.

U.S. House of Representatives, Committee on Ways and Means (1987-1993, 1998). Green Book. 